Article

\title{
Quantitative Estimation of Fougerite Green Rust in Soils and Sediments by Citrate-Bicarbonate Kinetic Extractions
}

\author{
Frédéric Feder ${ }^{1, * \mathbb{D}}$, Fabienne Trolard ${ }^{2,3} \mathbb{D}$, Guilhem Bourrié ${ }^{4}$ and Goestar Klingelhöfer 5 \\ 1 CIRAD, UPR Recyclage et Risque, LMI IE SOL, BP 1386, 18524 Dakar, Senegal \\ 2 INRA, UMR 1114 Emmah, CS 40509, F-84914 Avignon CEDEX 9, France; fabienne.trolard@inra.fr \\ UAPV, UMR 1114 Emmah, CS 40509, F-84914 Avignon CEDEX 9, France \\ AAF, F75015 Paris, France; guilhem.bourrie@inra.fr \\ 5 Institut für Anorganische und Analytische Chemie, Johannes Gutenberg-Universität Mainz, \\ Staudinger Weg 9, D-55099 Mainz, Germany; klingel@uni-mainz.de \\ * Correspondence: frederic.feder@cirad.fr; Tel.: +33-4-6761-4944
}

Received: 15 August 2018; Accepted: 27 September 2018; Published: 1 October 2018

\begin{abstract}
Fougerite (IMA 203-057), from green rust (GR) group, is difficult to quantify due to its reactivity and its small concentration in soils and sediments. Chemical extractions with citrate-bicarbonate $(\mathrm{CB})$ reagent, in kinetic mode, can be used for a pre-diagnosis. Performed by steps $(0,1,6,48,168$ and $504 \mathrm{~h})$, the proposed protocol was applied on samples from Gleysol of Fougère's forest with mineralogical controls by Mössbauer and XRD (X-ray diffraction) after each step of extraction. In less than $6 \mathrm{~h}$, the first fraction extracted is composed of $70 \% \mathrm{Si}, 80 \% \mathrm{Al}, 23 \% \mathrm{Fe}$ and $80 \% \mathrm{Mg}$ of total element extractable by $\mathrm{CB}$ and is ascribed to the "indefinable mineral mixture $\mathrm{Si}-\mathrm{Al}-\mathrm{Fe}^{\prime \prime}$ named by Tamm. Between 6 and $168 \mathrm{~h}$, the second fraction extracted is composed of Fe and $\mathrm{Mg}$ with a constant mole ratio $\mathrm{Fe} / \mathrm{Mg}$ equal to 10 and is ascribed to the fougerite-GR phase. Analysis of XRD pattern and of Mössbauer spectra confirms: (i) all the other mineral phases containing Al, $\mathrm{Mg}$, Si were not dissolved by CB after $6 \mathrm{~h}$; (ii) the CB treatment extracts fougerite-GR completely. The residual fraction is composed of components not dissolved by CB extraction. Thus, the selectivity of $\mathrm{CB}$ can be used to quantitatively estimate the presence of fougerite-GRs in soils and sediments.
\end{abstract}

Keywords: green rust; fougerite; citrate-bicarbonate extraction; Mössbauer; iron; Fe; gley; hydromorphy

\section{Introduction}

In many environments, iron (Fe) minerals play a major role in biogeochemical cycles as electron donor and acceptor in oxidoreduction reactions. Soil genesis and properties are frequently influenced by Fe in soil solution and in minerals [1,2]. Many years ago, blue and green colors in reduced soils were associated with ferrous iron in solution and mixed $\mathrm{Fe}^{2+}$ and $\mathrm{Fe}^{3+}$ hydroxides, known as green rusts (GRs) [3-5]. They were suspected but unidentified in soils [6]. Natural GRs were recognized in soils for the first time by Trolard et al. [7,8] and fougerite, the natural GR, has been approved as a new mineral by the International Mineralogical Association (IMA) with the number 2003-057 [9]. Fougerite is a mixed M(II)-M(III) hydroxide of the GR group (or Layered Double Hydroxides LDH), where M(II) can be Fe or magnesium $(\mathrm{Mg})$, and $\mathrm{M}(\mathrm{III})$ Fe. The general structural formula is $\left[\left(\mathrm{Fe}^{2+}, \mathrm{Mg}^{2+}\right)_{1-\mathrm{x}} \mathrm{Fe}^{3+}{ }_{\mathrm{x}}\right.$ $\left.(\mathrm{OH})_{2}\right]^{\mathrm{x}+}\left[\mathrm{x} / \mathrm{n} \mathrm{A}^{-\mathrm{n}}, \mathrm{mH}_{2} \mathrm{O}\right]^{\mathrm{x}-}$, where $x=\mathrm{Fe}^{3+} /(\mathrm{Fe}+\mathrm{Mg})_{\mathrm{tot} .}, A$ is the interlayer anion and $n$ its valency, with $1 / 4 \leq \mathrm{x} \leq 1 / 3$ and $\mathrm{m} \leq(1-\mathrm{x})$. The structure of GRs and parent minerals can accommodate a variety of anions, such as $\mathrm{OH}^{-}, \mathrm{Cl}^{-}, \mathrm{CO}_{3}{ }^{2-}, \mathrm{SO}_{4}{ }^{2-}[9,10]$. Iron control and equilibria between soil 
solution and natural GRs were demonstrated in hydromorphic soils and constrain a narrow range of the GRs chemical composition [11,12].

Understanding the thermodynamic conditions of precipitation, equilibrium, and dissolution of natural or synthetic GRs is fundamental both to the current functioning of soils and sediments and to the genesis of iron-bearing geological formations. Under the geochemical and thermodynamic conditions prevailing in the oceans during the Precambrian era, GRs played a fundamental role in the genesis of iron formation [13] and even likely in the origin of life [14]. These geochemical conditions are similar to those currently being measured in reductive soils. The study of the thermodynamic equilibria between natural GRs and soil solution made it possible to establish a ternary solid solution model $[10,15]$ taking into account the partial substitution of $\mathrm{Fe}^{2+}$ by $\mathrm{Mg}^{2+}$ [16]. There is a complex nexus of interactions between GRs, trace metals and metalloids. For example, GRs rapidly and completely reduce chromate ( $\mathrm{Cr}(\mathrm{VI}))$ into $\mathrm{Cr}(\mathrm{III})$ [17]. Conversely, aqueous Fe(II), that can be released by GRs dissolution, can promote recrystallization of $\mathrm{Cr}$-substituted goethites [18] with liberation of $\mathrm{Cr}$ in solution. In addition, the presence of certain metalloids such as arsenic (As) or antimony (Sb) [19] or changes in oxidation-reduction conditions [20] influence the precipitation or transformation of synthetic GRs.

GRs are unstable in air and transform easily by oxidation into $\mathrm{Fe}^{3+}$-oxides (lepidocrocite, goethite); this transformation is accompanied by a color change of the sample from blue to ochre [1]. A special cell is necessary to keep the sample in nitrogen or argon atmosphere [7]. Thus, natural GRs are difficult to conserve, describe and analyze. XRD (X-ray diffraction) patterns, recorded on soils, fail to provide clear evidence about fougerite-GR mineral due to the diffuse and dilute nature of this mineral and the frequent presence of other dominant minerals such as kaolinite, whose diffraction peaks are very close to those of synthetic GRs, except with special data treatment with DECOMPXR software [15]. Chemical analyses of the whole soil could be performed but the natural mineral cannot be separated due to its labile character. Therefore, it is necessary to use more sensitive and specific techniques namely Mössbauer spectroscopy [7,8,12] or X-ray absorption spectroscopy at the Fe-K edge [16].

Beyond these strict mineralogical characterizations, some chemical methods have been developed to quantify specific reactive compartments after dissolution. Chemical extractions have been commonly used in soil science with this objective and the results used to compare soils from different origins [2,21]. Thus, several chemical reagents have been used to distinguish organic and/or mineral fractions and then to define diagnostic horizons and properties. Though these extractions are not specific of well-known mineralogical phases $[1,22]$ they have been frequently used to define reference soil groups affected by different pedogeneses [23]. For example, organically bound $\mathrm{Fe}$ and aluminum (Al) can be extracted with a pyrophosphate solution. Free $\mathrm{Fe}$, manganese $(\mathrm{Mn})$ and $\mathrm{Al}$ in soils can be extracted using Dithionite-Citrate-Bicarbonate (DCB) reagent at high temperature, i.e., $60{ }^{\circ} \mathrm{C}[18]$ or at room temperature with a kinetic procedure [24-26]. Short-range-ordered or amorphous $\mathrm{Fe}, \mathrm{Al}$, and silica (Si) compounds are commonly extracted by an acid ammonium oxalate solution [27] particularly to refine XRD patterns on clay minerals [28] or by extraction by CB reagent [26] in alkaline conditions with the advantage that clay minerals are not dissolved. However, the procedure with ammonium oxalate cannot be used to dissolve GRs because oxalate anion can be incorporated in the structure to form a stable oxalate-GR [10]. Nevertheless, the CB reagent, i.e., DCB without the reductive contribution of dithionite, can be used to dissolve completely, in a few hours, synthetic GRs [7]. However to validate this procedure as a specific means of quantifying the amount of natural GR-fougerite in a soil sample, it is necessary to study the kinetics of elements released in solution associated with mineralogical controls step-by-step on the solid residue. This approach was used to define all the duration of common extraction procedure and sometimes to explain the association or the substitution of a specific element in some mineralogical phases [29,30].

Currently, there is no easily accessible method to identify GR, or to quantify the substitution of iron by magnesium. Therefore, this paper aims at assessing the selectivity of $\mathrm{CB}$ reagent to dissolve natural GRs and proposes a protocol to estimate their quantity present in soils or sediments by measurement 
of Fe and $\mathrm{Mg}$ dissolved with $\mathrm{CB}$ extractions. The adopted strategy is founded on: (i) analyzing the $\mathrm{Si}$, $\mathrm{Al}$, Fe and $\mathrm{Mg}$ concentrations released by $\mathrm{CB}$ extraction as function of time and (ii) controlling by $\mathrm{XRD}$ and Mössbauer spectroscopy the evolution of mineral phases in the residue during these extractions.

\section{Materials and Methods}

\subsection{Sampling Site}

The soil profile studied is localized in the domanial forest $\left(15 \mathrm{~km}^{2}\right)$ at Fougères in Brittany, France $\left(48^{\circ} 25^{\prime} \mathrm{N}, 1^{\circ} 10^{\prime} \mathrm{W}\right)$. Climatic conditions are oceanic, influenced by the Channel sea (50 $\mathrm{km}$ to the North) and the Atlantic Ocean. Vegetation is composed with oak and especially beech and minor species (holly, fern, nettle, and bramble). Altitude is $180 \mathrm{~m}$ above sea level at the bottom of a hill cut by numerous thalwegs into small watersheds, about $800 \mathrm{~m}$ long. The site is located near a spring, at about $200 \mathrm{~m}$ from the top of a hill. Soils are developed in a granitic saprolite (several meters thick) derived from the weathering of a granodiorite with cordierite. This saprolite is covered by two different silty formations. The deeper one is the result of in situ saprolite evolution and the second one is a loess deposition during the last glaciation (Weichselian), as evidenced by the discontinuities in grain size distribution at 30 and $70 \mathrm{~cm}$ depth (Table 1). The clay fraction, i.e., particle size $<2 \mu \mathrm{m}$, is maximum near $65 \mathrm{~cm}$ at the top of granitic saprolite. The profile chosen is situated in a soil catena made of Cambisols upslope and Gleysols downslope [21].

Table 1. $\mathrm{pH}_{\text {water, }} \mathrm{pH}_{\mathrm{KCl}}$, carbon contents, total cation exchange capacity (CEC) and particle size distribution for the different horizons.

\begin{tabular}{|c|c|c|c|c|c|c|c|c|}
\hline Depth $^{1}$ & \multirow{2}{*}{$\mathrm{pH}_{\text {water }}$} & \multirow{2}{*}{$\mathrm{pH}_{\mathrm{KCl}}$} & $\mathrm{C}$ & CEC & $\mathrm{CF}^{\mathrm{a}}$ & $\mathrm{FS}^{\mathrm{a}}$ & $\mathrm{CS}^{\mathrm{a}}$ & \multirow{2}{*}{$\mathbf{S}^{\mathbf{b}}$} \\
\hline $\mathrm{cm}$ & & & $\%$ & $\mathrm{cmol}_{(+)} \cdot \mathrm{kg}^{-1}$ & $\mathrm{~g} \cdot \mathrm{kg}^{-1}$ & $\mathrm{~g} \cdot \mathrm{kg}^{-1}$ & $\mathrm{~g} \cdot \mathrm{kg}^{-1}$ & \\
\hline $\begin{array}{c}10 \\
(\mathrm{OH} / \mathrm{AG})\end{array}$ & 4.5 & 3.7 & 7.5 & 4.3 & 76 & 364.7 & 450.9 & 108.4 \\
\hline 35 (Go) & 4.5 & 3.7 & 1.6 & 1.7 & 109.6 & 262 & 536.5 & 91.9 \\
\hline $65(\mathrm{Gr})$ & 4.8 & 3.7 & 0.5 & 4.5 & 167.8 & 206.3 & 453 & 172.9 \\
\hline $75(\mathrm{Gr})$ & 4.2 & 3.4 & 0.4 & 4.9 & 119.5 & 185.3 & 278.9 & 416.3 \\
\hline 85 (Cg) & 5.2 & 4 & 0.7 & 5.2 & 118.8 & 197.4 & 150.1 & 533.7 \\
\hline 95 (Cg) & 4.8 & 3.7 & 0.4 & 6.1 & 98.6 & 182.8 & 131.4 & 587.3 \\
\hline
\end{tabular}

${ }_{1}^{1}$ corresponding horizon in brackets (cf. description in text); ${ }^{a} \mathrm{CF}=$ Clay Fraction $(<2 \mu \mathrm{m}), \mathrm{FS}=$ Fine Silt $(2-20 \mu \mathrm{m})$, CS = Coarse Silt $(20-50 \mu \mathrm{m})$ and $S=$ Sand $(50-2000 \mu \mathrm{m})$.

The soil profile is a Gleysol and the different horizons observed are:

- $\quad$ 0-15 cm (OH/AG): a black organic horizon above an organo-mineral horizon with a diffuse transition. No oxidoreduction mottles have been detected;

- $\quad$ 15-50 cm (Go): a silty horizon, with oximorphic properties, i.e., bluish-grey colors in cores (5 BG 6/1 according to Munsell's chart) with some discolorations along roots and numerous oxidoreduction mottles (specifically 5 Y $6 / 4$ and 2.5 Y $5 / 6$, moist); structure is massive and the piezometric level of the water table is frequently present in this horizon;

- $\quad 50-80 \mathrm{~cm}(\mathrm{Gr})$ : a silty horizon, with reducing conditions, i.e., homogeneous in color and clearly blue (5 BG 6/1), almost permanently waterlogged (10 months per year), without roots. No oxidoreduction mottles have been observed. Texture changes progressively from $60 \mathrm{~cm}$ to $80 \mathrm{~cm}$ and limit between $\mathrm{Gr}$ and $\mathrm{Cg}$ is diffuse;

- $\quad 80 \mathrm{~cm}$ and more $(\mathrm{Cg})$ : the granitic saprolite with reducing properties, i.e., bluish-green color (5 BG 6/1), permanently waterlogged.

\subsection{Soil Analysis}

Total $\mathrm{C}$ of the initial soil was determined by dry combustion with an element analyzer (CHNS-O EA 1108, Carlo Erba Instrument). Cation exchange capacity (CEC) was measured by 
the cobaltihexamine method at soil $\mathrm{pH}$ [31]. The $\mathrm{pH}$ water and $\mathrm{pH} \mathrm{KCl}$ were measured according to the NF ISO 10390 standard at a soil/water volume ratio of 1:5 [21].

\subsection{Soil Sampling}

The soil sample was collected in the reductic horizon $(\mathrm{Cg})$ in a large volume $\left(\mathrm{a}\right.$ few $\left.\mathrm{dm}^{3}\right)$ with the surrounding soil solution and maintained under anoxic conditions in an airtight box without sieving or air-drying. All the manipulations of this soil sample were performed inside a glove box under $\mathrm{N}_{2}$ atmosphere and with an oxygen trap. The permanence of the original blue or blue-green colors during all experiments is used as a preservation criterion.

\subsection{Chemical Extraction Procedure with $C B$}

In the glove box, $500 \mathrm{mg}$ of soil sample were mixed in a polypropylene bottle with $50 \mathrm{~mL}$ of CB reagent. Soil/solution ratio is ca. 1 for 100 in weight. To prepare CB reagent, mix $9.82 \mathrm{~g}$ of sodium bicarbonate $\mathrm{NaHCO}_{3}\left(\mathrm{M}=84 \mathrm{~g} \cdot \mathrm{mol}^{-1}\right)$ with $78.43 \mathrm{~g}$ of tri-sodium-citrate $\mathrm{Na}_{3} \mathrm{C}_{6} \mathrm{H}_{5} \mathrm{O}_{7}, 2 \mathrm{H}_{2} \mathrm{O}$ $\left(\mathrm{M}=294.1 \mathrm{~g} \cdot \mathrm{mol}^{-1}\right)$ in 1 liter of ultra-pure water [30,32]. CB extractions were realized in separate bottles during 1, 6, 48, 168, 336 and $504 \mathrm{~h}$ with one repetition at each time of reaction. All samples were shaken three times a day. Extraction solutions were collected and filtered at $0.45 \mu \mathrm{m}$ under $\mathrm{N}_{2}$ atmosphere immediately with Millipore ${ }^{\mathrm{TM}}$ filters and then acidified with supra-pure $\mathrm{HNO}_{3}$. Analyses of $\mathrm{Si}, \mathrm{Al}, \mathrm{Fe}$ and $\mathrm{Mg}$ were quickly performed by inductively coupled plasma-atomic emission spectrometry (ICP-AES); the relative precision of measured concentrations ranges from $2 \%$ to $5 \%$.

\subsection{X-Ray Diffraction}

XRD patterns were recorded on soil samples using a Siemens D5000 (40 kV, $20 \mathrm{~mA})$ diffractometer with a graphite monochromator, Bragg-Brentano geometry, and Co-K $\alpha 1$ radiation $(\lambda=1.7890 \AA)$. The dwell time in the $2-45^{\circ}$ interval $(2 \theta)$ was set to $1 \mathrm{~s}$ per $0.02^{\circ}$ step (i.e., a total of about $1 \mathrm{~h}$ ) on a rotating sample. The main crystalline phases (starting at a few percent) were indexed using Diffrac-AT software linked to the 1998 JCPDS database. Initial soil sample was also saturated with $\mathrm{K}, \mathrm{Mg}$ and ethylene-glycol or heated to 350,450 and $550{ }^{\circ} \mathrm{C}$ following the classical protocol to distinguish the main clay minerals [2,33]. XRD patterns were also recorded after $168 \mathrm{~h}$ of $\mathrm{CB}$ extraction on the initial soil sample. Collected after filtration under $\mathrm{N}_{2}$ atmosphere inside the glove box, this treated sample was analyzed into an airtight cell specifically built up for this diffractometer. Then, this soil sample was heated at $550{ }^{\circ} \mathrm{C}$ and another XRD pattern was recorded.

\subsection{Mössbauer Spectroscopy}

As any Mössbauer spectrometer dedicated to iron, the instrument consists of (i) a source of $14.4 \mathrm{keV} \gamma$-ray, (ii) a drive generating by Doppler effect a variation of the incident wavelength, and (iii) detectors. Thus, Mössbauer spectrum is presented with the velocity of the source in $\mathrm{mm} \cdot \mathrm{s}^{-1}$ in abscissa and the number of $\gamma$-rays emitted by the soil sample in ordinate. The instrument, initially designed for Mars missions requires high detection efficiency. Our Mössbauer spectrometer operates in backscattering geometry and not in classical transmission [34]. The comparison of spectra obtained by transmission or backscattering did not show any significant experimental differences [34]. Backscattering geometry is not influenced by the sample thickness. The main disadvantage is the secondary radiation caused by primary $122 \mathrm{keV}$ radiations, for which an effective shielding of the detectors was designed. Si-PIN diodes were used as detectors, with efficiencies nearly $100 \%$ and $65 \%$ for 6.4 and $14.4 \mathrm{keV}$ radiations, respectively. The velocity was calibrated with a $25 \mu \mathrm{m}$ foil of $\alpha$-Fe at room temperature (RT) and the isomer shifts will thus be given with respect to this reference. The electron density at the nucleus determines the isomer shift $\delta$. Thus, $\delta$ reflects specifically the oxidation states: $\mathrm{Fe}^{2+}$ or $\mathrm{Fe}^{3+}$. The quadrupole splitting $\Delta E_{Q}$ originates from non-uniform charge density and electric field gradient interactions with the iron nucleus. $\Delta E_{Q}$ is influenced by the crystallinity, specifically by site distortion [1]. Our Mössbauer spectroscopy measurements were always done at RT. The Mössbauer 
spectra were fitted with Lorentzian functions. A set of free parameters was then adjusted to minimize a goodness-of-fit criterion, the $\chi^{2}$. The free parameters are those that are only mutually bounded via the $\chi^{2}$ minimization procedure. These parameters are the isomer shift $\delta$, the quadrupole splitting $\Delta E_{Q}$, the widths at half maximum and the height of the peaks, constrained to be equal for both lines of the doublet. The precision obtained on the $x=\mathrm{Fe}^{3+} / \mathrm{Fe}_{\text {tot. }}$. ratio is better than the precision on each individual doublet, as errors partly compensate, and can be estimated as \pm 0.01 by analyzing several samples several times. Quality of spectra depends essentially on iron concentration in the samples and duration of acquisition. The relative abundance of components is obtained by integration of the corresponding areas. Line intensities are directly proportional to the site abundance and vary from a mineral to another. Collected after filtration under $\mathrm{N}_{2}$ atmosphere inside the glove box, these residual solid soils were placed into an airtight cell specifically built up for this Mössbauer spectrometer. Mössbauer spectra were recorded after 6, 48, 168 and $504 \mathrm{~h}$ of CB extraction on the initial soil sample.

\section{Results}

The original blue-green color of samples was preserved during all experiments, which indicates that reductive conditions were maintained in the glove box. Oxidation of soil sample, i.e., transformation of fougerite-GR to lepidocrocite [1], would have been easily detected by the ochre coloration and the $6.26 \AA$ peak on XRD patterns, that was not observed (cfinfra).

\subsection{Kinetic Selective Extractions}

Kinetic extraction of $\mathrm{Si}, \mathrm{Al}, \mathrm{Fe}$ and $\mathrm{Mg}$ by $\mathrm{CB}$ show different behaviors with time (Figure 1). Cumulative extracted fraction is expressed in percentage of the total absolute concentration of the element in the soil. Cumulated concentrations of Si extracted by CB were $1.3 \%$ after only $6 \mathrm{~h}$ and reached slowly $1.8 \%$ after $504 \mathrm{~h}$ (Table 2). Kinetic extraction of Al followed another pattern: Al extracted by CB increased quickly to $9.4 \%$ till $6 \mathrm{~h}$ and gradually until $48 \mathrm{~h}$ to reach $11.8 \%$ and remained constant till $504 \mathrm{~h}$. Cumulated concentrations of Fe and $\mathrm{Mg}$ extracted by CB showed a pattern with three stages: at first, $\mathrm{Fe}$ and $\mathrm{Mg}$ concentrations in solution increased quickly respectively to $22.9 \%$ and $55.8 \%$. During the second stage, between 8 and $168 \mathrm{~h}$, Fe and $\mathrm{Mg}$ were released linearly till $97.1 \%$ and $69.1 \%$, respectively until $168 \mathrm{~h}$. Finally, Fe and Mg remained constant from 168 to $504 \mathrm{~h}$.

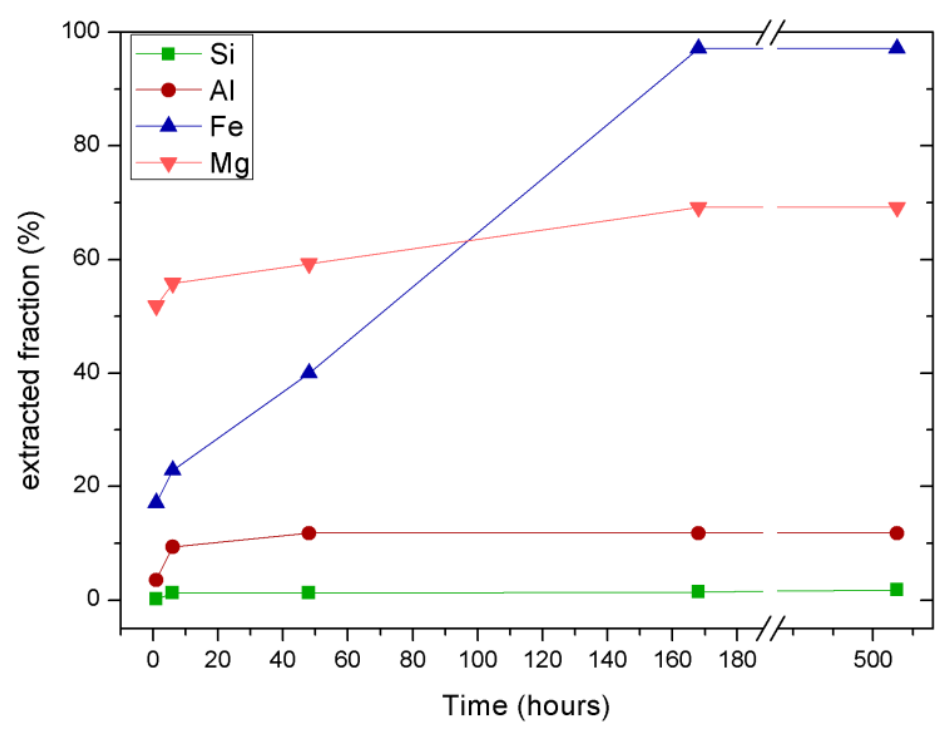

Figure 1. Kinetic extractions of $\mathrm{Si}, \mathrm{Al}, \mathrm{Fe}$ and $\mathrm{Mg}$ by citrate-bicarbonate. 
Table 2. Total and exchangeable concentration of $\mathrm{Si}, \mathrm{Al}, \mathrm{Fe}$ and $\mathrm{Mg}$ in initial soil and after $\mathrm{CB}$ extractions as function of time.

\begin{tabular}{|c|c|c|c|c|c|}
\hline & & $S i^{a}$ & $\mathrm{Al}^{\mathrm{a}}$ & $\mathrm{Fe}^{\mathrm{a}}$ & $\operatorname{Mg}^{\mathrm{a}}$ \\
\hline \multirow{2}{*}{ Initial soil } & total & 11,000 & 1700 & 700 & 405 \\
\hline & exchangeable & 0 & 1 & 0.9 & 15.5 \\
\hline \multirow{2}{*}{ Time of CB } & 1 & 20 & 60 & 120 & 105 \\
\hline & 6 & 140 & 160 & 160 & 226 \\
\hline \multirow{4}{*}{ Extraction (hours) } & 48 & 140 & 200 & 280 & 240 \\
\hline & 168 & 160 & 200 & 680 & 280 \\
\hline & 336 & 180 & 200 & 680 & 280 \\
\hline & 504 & 200 & 200 & 680 & 280 \\
\hline
\end{tabular}

${ }^{\mathrm{a}}$ expressed in $\mathrm{mmol} \cdot \mathrm{kg}^{-1}$.

$\mathrm{Si}, \mathrm{Al}, \mathrm{Fe}$ and $\mathrm{Mg}$ are present in different mineral phases dissolved separately by $\mathrm{CB}$ during time. Evidence for this is obtained by plotting the results of kinetic extractions of $\mathrm{Si}, \mathrm{Al}, \mathrm{Fe}$ and $\mathrm{Mg}$ versus each other (Figure 2) [30]. These elements never showed continuous and simple congruent dissolution. After $1 \mathrm{~h}$ of extraction by $\mathrm{CB}$, the couples $(\mathrm{Fe}, \mathrm{Si}),(\mathrm{Fe}, \mathrm{Al})$ and $(\mathrm{Al}, \mathrm{Si})$ were close to the 1:1 bisector, corresponding to a congruent dissolution. Nevertheless, after $6 \mathrm{~h}$, only the couple $(\mathrm{Al}, \mathrm{Si})$ was still close to the bisector. After $6 \mathrm{~h}$, all couples of elements were far away from the bisector or crossed it at the end of the extraction by $\mathrm{CB}$, which does not allow for an unequivocal interpretation of these extraction data. Only Mg was significantly present as exchangeable ions (Table 2) and is quickly released before iron phases.
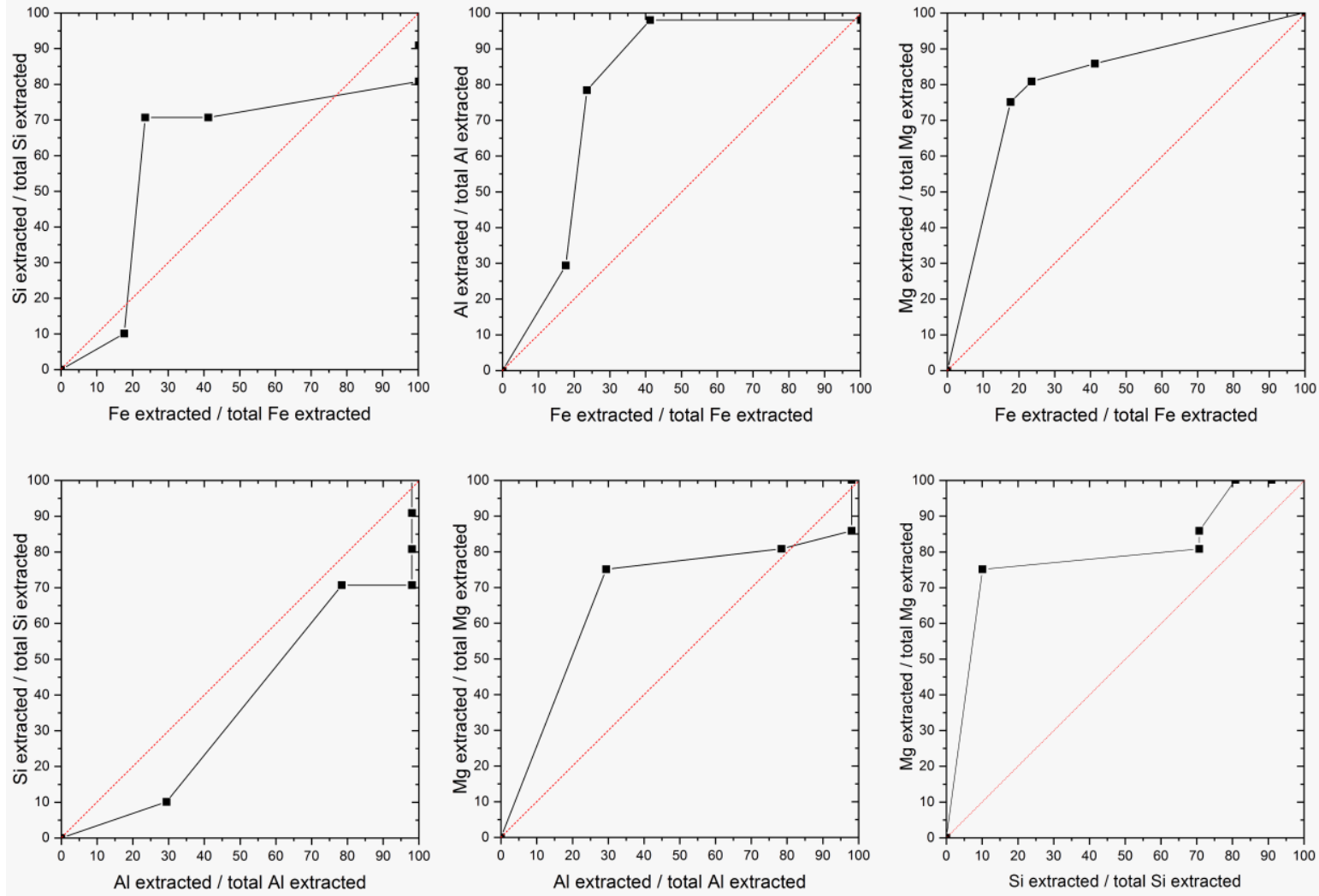

Figure 2. Plots of the results of kinetic extractions by $\mathrm{CB}$ of $\mathrm{Si}, \mathrm{Al}, \mathrm{Fe}$ and $\mathrm{Mg}$ versus each other. 


\subsection{XRD Patterns}

Even after $168 \mathrm{~h}$ of CB treatment, none of the main peaks of silicates were significantly affected. The raw diagrams, with the different treatments presented in material and methods, are shown in Figure 3.

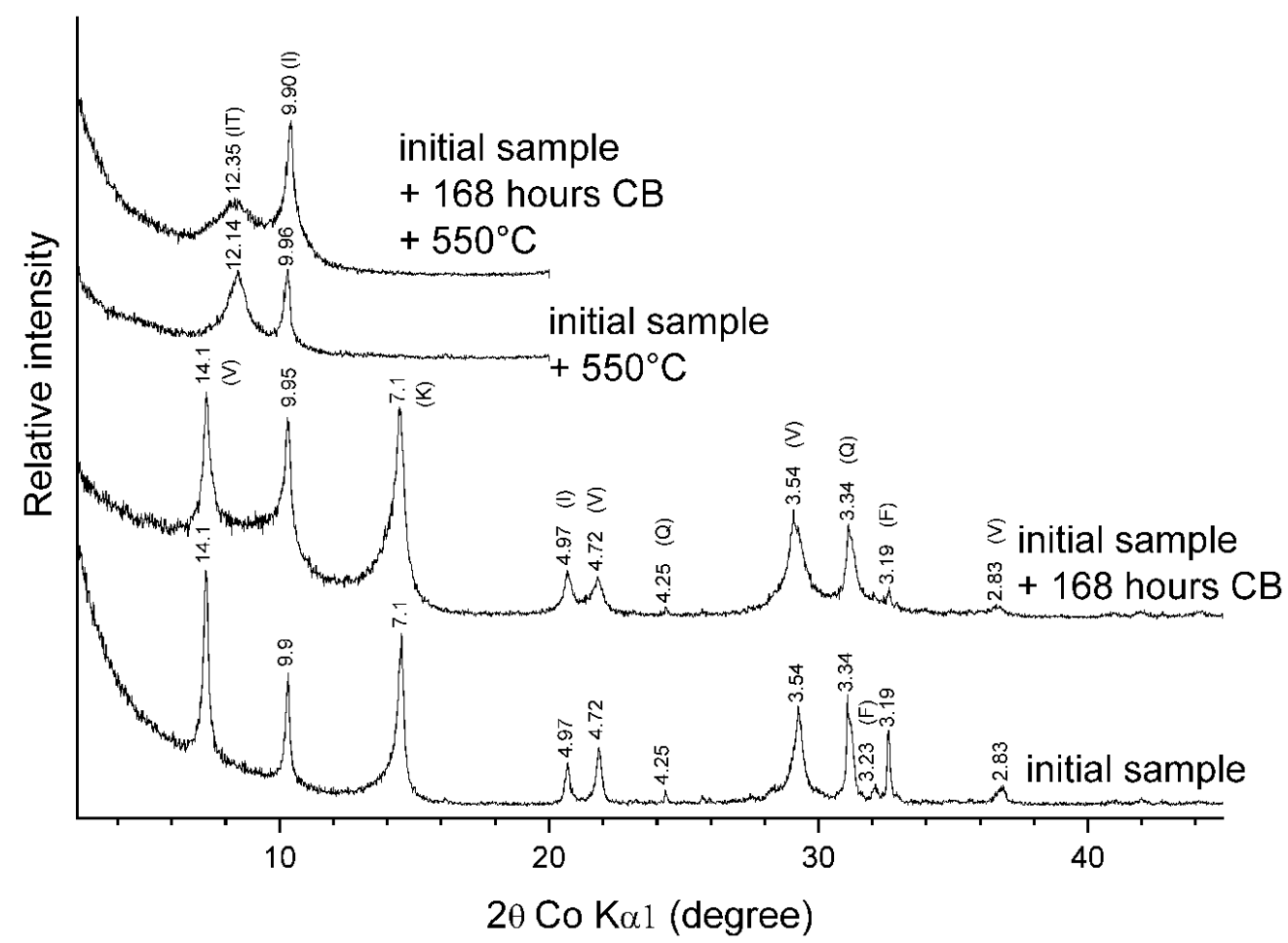

Figure 3. From down to top, XRD patterns of initial soil sample, soil sample after $168 \mathrm{~h}$ of $\mathrm{CB}$ treatment and after heating at $550{ }^{\circ} \mathrm{C}$ of initial soil sample and after $168 \mathrm{~h}$ of $\mathrm{CB}$ treatment. $\mathrm{Q}=$ quartz, $\mathrm{F}=$ feldspar, $\mathrm{K}=$ kaolinite, $\mathrm{I}$ = illite, $\mathrm{V}$ = vermiculite, $\mathrm{IT}$ = intergraded mineral.

For the initial sample, quartz (Q: $3.34 \AA$ ), K-feldspar and plagioclase-feldspar (F: 3.23 and $3.19 \AA$ ) are identified. The $7.1 \AA$ peak, which disappears after heating at $550{ }^{\circ} \mathrm{C}$, is characteristic of kaolinite $(\mathrm{K})$. The $9.94 \AA$ A peaks, that does not collapse with $\mathrm{K}$ saturation (raw diagram not shown), can be ascribed to illite (I). The $14.1 \AA$ A peak that does not collapse with $\mathrm{K}$ or ethylene-glycol saturation as with true vermiculites $(\mathrm{V})$ but disappears on heating and shifts to $12.14 \AA$ A can be assigned to an intergraded mineral (IT) with some hydroxyl-ion interlayer because true chlorites would shift to $10 \AA$. After $6 \mathrm{~h}$ of CB extraction (not represented here), peak of interstratified minerals appears between 14.1 and $9.95 \AA$ and persists unchanged until the end of the extractions (see XRD pattern of soil sample $+168 \mathrm{~h} \mathrm{CB}$ ). No iron oxide or oxy-hydroxide have been observed by XRD.

\subsection{Mössbauer Spectra}

Mössbauer spectra measured at RT with the computed hyperfine interaction parameters display the same characteristic quadrupole ferrous and ferric doublets as the fougerite obtained in situ [12]. Mössbauer spectrum of initial soil sample before CB treatment is given on Figure 4. Hyperfine interaction parameters obtained from computer fitting with Lorentzian-shape lines are given in Table 3. All the spectra had to be fitted with three quadrupole doublets. D1 and D2 correspond to ferrous ion sites and D3 correspond to ferric ion sites. According to the crystal structure of GR, the Mössbauer spectra of the compound were first fitted with only two doublets D1 and D3 for each crystal site. This fit proved unsatisfactory and then the D2 doublet had to be added. These parameters correspond to the description of fougerite (IMA 2003-057) [9]. No other iron phases have been observed, the $x=\mathrm{Fe}^{3+} / \mathrm{Fe}_{\text {tot. }}$ mole ratio was 0.43 and global spectrum quality was excellent. 
Table 3. Hyperfine interaction parameters of Mössbauer spectra obtained at room temperature. D1, D2 and D3 are the three doublets (cf. Figure 4). $\delta$ is the isomer shift (in $\mathrm{mm} \cdot \mathrm{s}^{-1}$ ) with respect to the $\alpha$-Fe foil reference, $\Delta \mathrm{E}_{\mathrm{Q}}$ is the quadrupole splitting (in $\mathrm{mm} \cdot \mathrm{s}^{-1}$ ) and RA is the Relative Area of the components (in \%). $x=\mathrm{Fe}^{3+} / \mathrm{Fe}_{\text {tot. }}$ is equal to the relative area of $\mathrm{D} 3$ doublet; the estimation error on $x$ is \pm 0.01 .

\begin{tabular}{|c|c|c|c|c|c|c|c|c|c|}
\hline \multirow{2}{*}{ Samples } & \multicolumn{3}{|c|}{ D1 } & \multicolumn{3}{|c|}{ D2 } & \multicolumn{3}{|c|}{ D3 } \\
\hline & $\delta$ & $\Delta \mathrm{E}_{\mathrm{Q}}$ & RA & $\delta$ & $\Delta \mathrm{E}_{\mathrm{Q}}$ & RA & $\delta$ & $\Delta \mathrm{E}_{\mathrm{Q}}$ & RA \\
\hline initial & 1.05 & 2.62 & 50.9 & 0.89 & 2.41 & 6.1 & 0.25 & 0.80 & 43.0 \\
\hline$+6 \mathrm{~h} \mathrm{CB}$ & 1.04 & 2.68 & 54.6 & 0.84 & $2 ; 29$ & 4.8 & 0.30 & 0.71 & 40.6 \\
\hline$+48 \mathrm{~h} \mathrm{CB}$ & 1.05 & 2.67 & 56.9 & 0.83 & 2.39 & 8.5 & 0.30 & 0.68 & 34.6 \\
\hline$+168 \mathrm{~h} \mathrm{CB}$ & \multicolumn{9}{|c|}{ No spectrum } \\
\hline +504 h CB & \multicolumn{9}{|c|}{ No spectrum } \\
\hline
\end{tabular}

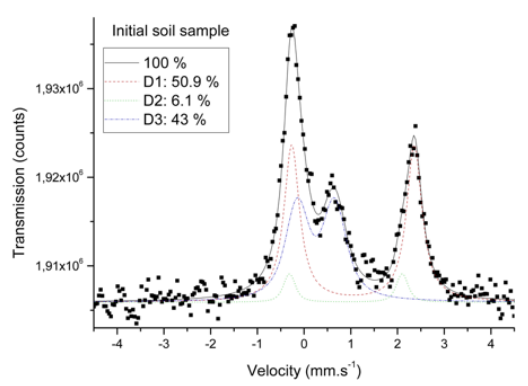

(a)

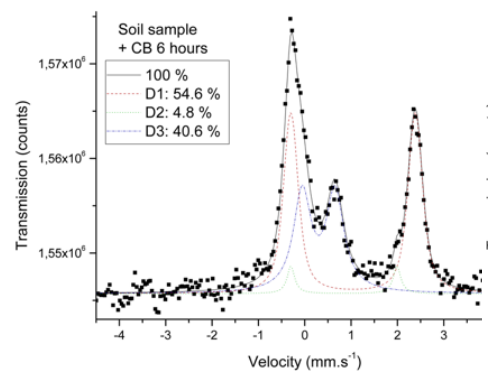

(b)

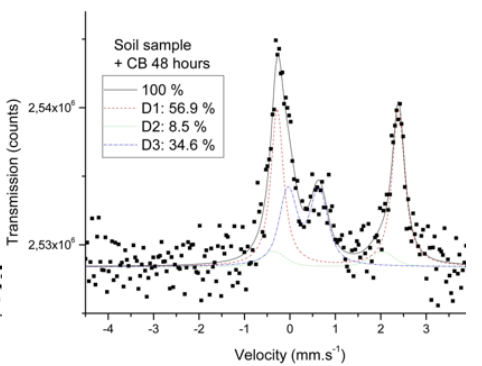

(c)

Figure 4. Mössbauer spectra of soil samples: (a) initial; (b) after $6 \mathrm{~h}-\mathrm{CB}$ extraction and (c) after $48 \mathrm{~h}-\mathrm{CB}$ extraction.

\section{Discussion}

In these selective extractions $\mathrm{CB}$ acts only as a single complexing agent in a medium, which is slightly alkaline ( $\mathrm{pH}$ 7.8) by the buffering effect of sodium bicarbonate [32]. Thus, results show that three different compartments of reactivity can be distinguished by $\mathrm{CB}$ extractions as a function of time (Figure 1).

- The first fraction, F1, extractable for a duration less than $10 \mathrm{~h}$, is composed of an "indefinable mixture" of $\mathrm{Al}, \mathrm{Si}, \mathrm{Fe}$ and $\mathrm{Mg}$. During this step, $70 \% \mathrm{Si}, 80 \% \mathrm{Al}, 23 \% \mathrm{Fe}$ and $80 \% \mathrm{Mg}$ extractable by $\mathrm{CB}$ are released in solution.

- The second fraction, F2, extractable between 6 and $168 \mathrm{~h}$, is essentially composed of Fe and Mg. During this time interval, $520 \mathrm{mmol} \mathrm{kg}^{-1}$ of Fe and $54 \mathrm{mmol} \mathrm{kg}^{-1}$ of $\mathrm{Mg}$ are released in solution with a constant mole ratio $\mathrm{Fe} / \mathrm{Mg}$ equal to 10 , whereas the $\mathrm{Al}$ and $\mathrm{Si}$ amounts are negligible.

- The third fraction, F3, is composed of the residual minerals, which are not dissolved by $\mathrm{CB}$ extraction.

The most labile mineral fraction F1 is very frequent in soils and, since 1922, Tamm proposed an extraction method based on the use of ammonium oxalate to remove it from solids, particularly from the clay fraction, and improve the quality of X-ray diagrams [28]. Tamm's method is one of the methods of selective extraction commonly used in soil science (e.g., [1,22]), but it is less selective than $\mathrm{CB}$ extraction because it acts on the solid by a double mechanism: complexation by oxalate and acid dissolution at $\mathrm{pH} 4.5$ [30].

Peak positions and intensities of the identified clay minerals (kaolinite, illite, vermiculite) were similar to those of the initial soil sample. Analysis of XRD pattern obtained after $168 \mathrm{~h}$ of CB treatment 
confirms that silicate minerals were not dissolved [35]. This previous result obtained by extraction with a buffered sodium dithionite solution on soil clays [35] was confirmed by extraction with a sodium-citrate solution on a dried and sieved soil sample from a nearby site [36]. Furthermore, cumulated concentration of Si extracted by CB treatment was very low and reached its maximum-1.3\% of absolute total concentration in the soil-only after $6 \mathrm{~h}$.

$\mathrm{Al}$ extracted by $\mathrm{CB}$ is a very small fraction of total $\mathrm{Al}$ (less than $2 \%$ ); it can be assigned essentially to intergrade vermiculites. Ethylene-glycol saturation and displacement of the peak to $12.14 \AA$ can be assigned to an intergrade mineral with some hydroxyl-ion interlayer as Al [33]. The presence of $\mathrm{Al}$ in the interlayers of vermiculites has been described long ago [37]. During this experimentation, $\mathrm{Al}$ was quickly extracted by $\mathrm{CB}$ : after just $6 \mathrm{~h}$, ca. $75 \%$ of Al extractible after $504 \mathrm{~h}$ was reached and $100 \%$ after $48 \mathrm{~h}$. This rate of $\mathrm{Al}$ extraction cannot be explained either by (i) the dissolution of silicate minerals because they are not dissolved; (ii) or by the dissolution of $\mathrm{Al}$ oxides because there is not any peak on XRD pattern [29]; (iii) or by the contribution of exchangeable $\mathrm{Al}$ because $\mathrm{Al}$ reached only $1 \mathrm{mmol}_{(+)} \cdot \mathrm{kg}^{-1}$ soil significantly lower than the CB extracted concentration (Table 2). Thus, intergrade vermiculites are the major phases to explain these concentrations of extractable Al by the CB. In addition, for the $12.35 \AA$ peak of the XRD patterns, the width at half height was broader and the height of the peak was twice less intense after the $\mathrm{CB}$ treatment and after the heating at $550{ }^{\circ} \mathrm{C}$. These results are consistent with another study with soil samples from the same site [36]. The authors identified these minerals as intergrade vermiculite with hydroxyl-ion interlayer: $\mathrm{Al}$ (mainly) and Fe. They realized extraction with sodium-citrate and after the extraction of high amounts of $\mathrm{Al}$, the mineral with $14 \AA$ peak behaved as true vermiculite. They confirmed these results with another approach: the analysis of the thermodynamic equilibria between these minerals and the soil solution. This complex paragenesis is classical in acid brown soils (Luvisols, [21]) on granite under oceanic climate.

From 0 to $168 \mathrm{~h}, \mathrm{CB}$ extracted more than $97 \%$ of total Fe in the soil and then fougerite-GR could not be identified by Mössbauer spectroscopy. CB extraction of Fe showed two main stages. The first one, from 0 to $6 \mathrm{~h}$, corresponds to the fougerite-GR phases extractible with CB and the iron minerals easily extractible by $\mathrm{CB}$ with the same kinetics than $\mathrm{Al}$ or $\mathrm{Mg}$ in intergrade mineral or easily extractible iron phases [29]. Al, mainly, and Fe were both present as some hydroxyl-ions in the interlayer of intergrade minerals and $\mathrm{Al}$ and $\mathrm{Fe}$ could be simultaneously extracted from intergrade minerals by successive citrate extractions [36]. The second stage occurred from 6 to $168 \mathrm{~h}$ and corresponds mainly to the fougerite-GR phase extractible with $\mathrm{CB}$ because all the other mineral phases containing $\mathrm{Al}, \mathrm{Mg}$, Si were not dissolved by CB after $6 \mathrm{~h}$.

For Mössbauer results, in the initial soil sample, $x$ ratio was $43 \%$ and after kinetic extraction by CB decreased continuously until $34.6 \%$ after $48 \mathrm{~h}$. These values of $x$ ratio are consistent with the field observation: from 0.34 to 0.64 [12].

Global quality of Mössbauer spectrum was still good after $6 \mathrm{~h}$ of CB treatment (Figure 4); but after $48 \mathrm{~h}$ of the $\mathrm{CB}$ extraction, peak intensities were smaller and differences between the experimental data and the computed curve were larger for this spectrum. A smaller amount of fougerite-GR could explain this spectrum quality. We have a confirmation of this trend with the total absence of Mössbauer spectrum (not shown) after 168 and $504 \mathrm{~h}$ of CB extraction (Table 3). This result is consistent with the first evidence of CB selectivity to dissolve synthetic GR [7].

The concentrations of $\mathrm{Mg}$ extracted by $\mathrm{CB}$ were close to the maximum values after $6 \mathrm{~h}$ of $\mathrm{CB}$ treatment. $\mathrm{Mg}$ originates mainly from fougerite-GR. Figure 2 shows that both Fe and $\mathrm{Mg}$ are released congruently between $6 \mathrm{~h}$ and $154 \mathrm{~h}$ of extraction. Thus, the $\mathrm{Mg}$ proportion in fougerite-GR can be quantified from CB extraction and estimated to $10 \%$. Relative differences between extracted amounts of $\mathrm{Mg}$ after $6 \mathrm{~h}$ and maximal values were close to $5 \%$. This confirms the partial substitution of $\mathrm{Fe}^{2+}$ by $\mathrm{Mg}^{2+}$ in fougerite observed by EXAFS and XANES [16]. 


\section{Conclusions}

Oxidoreduction processes couple biogeochemical cycles of Fe and many elements. Fougerite is a major ferriferous component of soils and sediments, and interacts with many major $(\mathrm{Mg}, \mathrm{N}, \mathrm{S})$, minor or trace elements, both metals $(\mathrm{Cu}, \mathrm{Hg}, \mathrm{Ag}, \mathrm{Au})$ and metalloids (Se, $\mathrm{As}, \mathrm{Sb})$. Its large reactivity involves abiotic and biotic processes. Extraction by $\mathrm{CB}$ in a kinetic mode can be used to establish a pre-diagnosis of occurrence of fougerite-GR mineral in soils and allows for quantifying its, especially in reductive environments. The procedure can be transposed to sediments. The disappearance of fougerite-GR, attested by Mössbauer spectroscopy, and the dynamics of Fe and Mg extraction by $\mathrm{CB}$ in kinetic mode prove the selectivity of $\mathrm{CB}$ procedure to dissolve fougerite-GR. The proposed protocol is given in Annex A. It is easier and cheaper than sophisticated spectroscopies, and well suited for soil survey studies. It allows for a first characterization and selection of samples for further studies e.g., by Mössbauer spectroscopy. In addition, analysis of elements released correlatively with Fe allows for identification of elements associated with fougerite by substitution or adsorbed on soil solid components.

Author Contributions: F.T., F.F. and G.K. conceived and designed the experiments; F.F. and G.K., performed the experiments; F.F., F.T., G.B. and G.K. analyzed the data; G.K. contributed to Mössbauer facilitations at Darmstadt University; F.F., F.T. and G.B. wrote the paper.

Funding: This research was funded by INRA (post-doctoral grant of G. Klingelhöfer), by the French "Programme National de Recherche Sol et Erosion" (PNSE) and by the Ministère de la Recherche (pre-doctoral grant F. Feder) .

Acknowledgments: Klingelhöfer G. acknowledges the support of the University Darmstadt, Germany, and the Germany Space Agency DLR, Bonn, Germany.

Conflicts of Interest: The authors declare no conflict of interest.

\section{Appendix A}

Protocol for extraction of fougerite GR with CB reagent.

Appendix A.1 Soil Sample

The soil sample must be collected in a large volume (a few $\mathrm{dm}^{3}$ ) with the surrounding soil solution if present and maintained under anoxic conditions in an airtight box without sieving or air-drying. All the manipulations of this soil sample must be performed inside a glove box under nitrogen atmosphere and with an oxygen trap.

\section{Appendix A.2 Reagent}

Preparation of $\mathrm{CB}$ reagent: mix $9.82 \mathrm{~g}$ of sodium bicarbonate $\mathrm{NaHCO}_{3}\left(\mathrm{M}=84 \mathrm{~g} \cdot \mathrm{mol}^{-1}\right)$ with $78.43 \mathrm{~g}$ of tri-sodium-citrate $\mathrm{Na}_{3} \mathrm{C}_{6} \mathrm{H}_{5} \mathrm{O}_{7}, 2 \mathrm{H}_{2} \mathrm{O}\left(\mathrm{M}=294.1 \mathrm{~g} \cdot \mathrm{mol}^{-1}\right)$ in 1 liter of ultra-pure water. Store in a bottle covered in foil.

\section{Appendix A.3 Procedure}

(1). In a glove box in darkness, weigh, in 12 separate $50 \mathrm{~mL}$ tubes, $500 \mathrm{mg}$ of soil sample. One or two repetitions at each time of reaction.

(2). Add $50 \mathrm{~mL}$ of $\mathrm{CB}$ reagent to each tube. Soil/solution ratio is ca. 1 for $100 \mathrm{in}$ weight.

(3). Close tubes and shake on high for $10 \mathrm{~min}$.

(4). After $1 \mathrm{~h}$, shake and collect supernatant solutions.

(5). Immediately, filter at $0.45 \mu \mathrm{m}$ with Millipore filters.

(6). Acidify with supra-pure $\mathrm{HNO}_{3}$.

(7). Repeat operation from points 4 to 6 for extraction after $6,48,168,336$ and $504 \mathrm{~h}$.

(8). Shake all samples three times a day. 
(9). Quickly perform analyses of $\mathrm{Si}, \mathrm{Al}, \mathrm{Fe}$ and $\mathrm{Mg}$ by inductively coupled plasma-atomic emission spectrometry (ICP-AES).

(10). Compute the \% of each element extracted relative to the total concentration of the element and plot the $\%$ of extraction vs. time (see Figure 1 ).

Warning: To obtain to the same day the supernatant solutions for analysis by (ICP-AES), plan the time of duration of extraction inversely to the collection of supernatant solutions.

\section{Appendix A.4 Method of Interpretation}

For the calculation we used here the experimental data given in this paper as example. The quantity of Fe extracted from fougerite is given by the difference between the number of millimol $/ \mathrm{kg}$ at the plateau and the intercept of the straight line with the vertical axis (see Figure 1), e.g., (see Table 2): $[\mathrm{Fe}(168 \mathrm{~h})]-[\mathrm{Fe}(48 \mathrm{~h})]=680-280=400 \mathrm{millimol} / \mathrm{kg}$. This amounts to $57 \%$ of total Fe in the soil (400/700). The quantity of Mg extracted from fougerite is obtained in the same way as: $[\mathrm{Mg}(168 \mathrm{~h})]-[\mathrm{Mg}(48 \mathrm{~h})]=280-240=40 \mathrm{millimol} / \mathrm{kg}$. Accordingly, $\mathrm{Mg}$ substitution for Fe amounts to $10 \%$.

The structural formula of fougerite can only be calculated if the ratio $\mathrm{Fe}^{3+} / \mathrm{Fe}_{\text {total }}$ is known, from Mössbauer spectroscopy. It is $43 \%$ in our sample (Table 3). Then the structural formula obtained is $\left[\left(\mathrm{Fe}^{2+}{ }_{0.51} \mathrm{Mg}^{2+}{ }_{0.09}\right) \mathrm{Fe}^{3+}{ }_{0.40}(\mathrm{OH})_{2}\right]^{0.4+}\left[0.4 \mathrm{~A}^{-}, \mathrm{mH}_{2} \mathrm{O}\right]^{0.4-}$, where $\mathrm{A}^{-}$the interlayered anion in fougerite, which cannot be determined by this method.

\section{References}

1. Cornell, R.M.; Schwermann, U. The Iron Oxides: Structure, Properties, Reactions, Occurrences and Uses; John Wiley \& Sons: New York, NY, USA, 2003.

2. Soil Survey Staff. Keys to Soil Taxonomy, 12th ed.; USDA-Natural Resources Conservation Service: Washington, DC, USA, 2014.

3. Vysotskii, G.N. Gley. Pochvovedeniye 1905, 4, 291-327.

4. Vysotskii, G.N. Gley. An abridged publication of Vysotskii 1905 on the 257th Anniversary of the Russian Academy of Science. Eurasian Soil Sci. J. 1999, 32, 1063-1068.

5. Ponnamperuma, F.N.; Tianco, E.M.; Loy, T. Redox equilibria in flooded soils: I. The ion hydroxide systems. Soil Sci. J. 1967, 103, 374-382. [CrossRef]

6. Bernal, J.D.; Dasgupta, D.R.; Mackay, A.L. The Oxides and Hydroxides of Iron and Their Structural Inter-Relationships. Clay Miner. Bull. 1959, 4, 15-21. [CrossRef]

7. Trolard, F.; Abdelmoula, M.; Bourrié, G.; Humbert, B.; Génin, J.-M.R. Mise en évidence d'un constituant de type "rouilles vertes" dans les sols hydromorphes-Proposition de l'existence d'un nouveau minéral: La "fougérite". CR Acad. Sci. 1996, 323, 1015-1022.

8. Trolard, F.; Génin, J.-M.R.; Abdelmoula, M.; Bourrié, G.; Humbert, B.; Herbillon, A.J. Identification of a green rust mineral in a reductomorphic soil by Mössbauer and Raman spectroscopies. Geochim. Cosmochim. Acta 1997, 61, 1107-1111. [CrossRef]

9. Trolard, F.; Bourrié, G.; Abdelmoula, M.; Refait, P.H.; Feder, F. Fougerite, a new mineral of the pyroaurite-iowaite group: Description and crystal structure. Clays Clay Miner. 2007, 55, 323-334. [CrossRef]

10. Bourrié, G.; Trolard, F.; Refait, P.H.; Feder, F. A solid-solution model for Fe(II)-Fe(III)-Mg(II) green rusts and fougerite and estimation of their Gibbs free energies of formation. Clays Clay Miner. 2004, 52, 382-394. [CrossRef]

11. Bourrié, G.; Trolard, F.; Génin, J.-M.R.; Jaffrezic, A.; Maître, V.; Abdelmoula, M. Iron control by equilibria between hydroxy-green rusts and solutions in hydromorphic soils. Geochim. Cosmochim. Acta. 1999, 63, 3417-3427. [CrossRef]

12. Feder, F.; Trolard, F.; Klingelhöfer, G.; Bourrié, G. In situ Mössbauer spectroscopy: Evidence for green rust (fougerite) in a gleysol and its mineralogical transformations with time and depth. Geochim. Cosmochim. Acta 2005, 69, 4463-4483. [CrossRef] 
13. Halevy, I.; Alesker, M.; Schuster, E.M.; Popovitz-Biro, R.; Feldman, Y. A Key Role for Green Rust in the Precambrian Oceans and the Genesis of Iron Formations. Nat. Geosci. 2017, 10, 135-139. [CrossRef]

14. Russell, M. Green rust: The simple organizing "seed" of all life. Life 2018, 8, 35. [CrossRef] [PubMed]

15. Trolard, F.; Bourrié, G. Chapter 5: Geochemistry of Green Rusts and Fougerite. Adv. Agronomy 2008, 99, 227-288.

16. Refait, P.H.; Abdelmoula, M.; Trolard, F.; Génin, J.-M.R.; Ehrhardt, J.J.; Bourrié, G. Mössbauer and XAS study of a green rust mineral; the partial substitution of $\mathrm{Fe}^{2+}$ by $\mathrm{Mg}^{2+}$. Amer. Mineralogist. 2001, 86, 731-739. [CrossRef]

17. Loyaux-Lawniczak, S.; Refait, P.; Ehrhardt, J.J.; Lecomte, P.; Génin, J.M.R. The reduction of chromate ions by Fe(II) layered hydroxides. Hydrol. Earth Syst. Sci. 1999, 3, 593-599. [CrossRef]

18. Hua, J.; Chen, M.; Liu, C.; Li, F.; Long, J.; Gao, T.; Wu, F.; Lei, J.; Gu, M. Cr release from Cr-substituted goethite during aqueous Fe(II) induced recrystallization. Minerals 2018, 8, 367. [CrossRef]

19. Karimian, N.; Johnston, S.G.; Burton, E.D. Antimony and Arsenic Behavior during Fe(II)-Induced Transformation of Jarosite. Environ. Sci. Technol. 2017, 51, 4259-4268. [CrossRef] [PubMed]

20. Jones, A.; Cassandra, M.; Murphy, A.; Waite, T.D.; Collins, R.N. Fe(II) Interactions with Smectites: Temporal Changes in Redox Reactivity and the Formation of Green Rust. Environ. Sci. Technol. 2017, 51, 12573-12582. [CrossRef] [PubMed]

21. IUSS Working Group WRB. World Reference base for Soil Resources 2014. International Soil Classification System for Naming Soils and Creating Legends for Soil Maps; World Soil Resources; Reports No. 106; Food and Agriculture Organization: Rome, Italy, 2014.

22. Borggaard, O.K. Phase identification by selective dissolution techniques. In Iron in Soils and Clay Minerals; Stucki, D., Ed.; Reibel Publishing Company: Dordrecht, The Netherlands, 1988; pp. 83-98.

23. Feder, F. Soil map update: Procedure and problems encountered for the island of Réunion. Catena 2013, 110, 215-224. [CrossRef]

24. Mehra, O.P.; Jackson, M.L. Iron oxides removal from soils and clays by a dithionite-citrate system buffered with sodium bicarbonate. Clays Clay Miner. 1960, 7, 317-327. [CrossRef]

25. Tessier, A.; Campbell, P.G.C.; Bisson, M. Sequential Extraction Procedure for the Speciation of Particulate Trace Metals. Anal. Chem. 1979, 51, 844-851. [CrossRef]

26. Jeanroy, E.; Guillet, B.; Delcroix, P.; Janot, Ch. Les formes du fer dans les sols: Confrontation des méthodes chimiques avec la spectrométrie Mössbauer. Sci. Sol. 1983, 3-4, 185-194.

27. Alary, K.; Babre, D.; Caner, L.; Feder, F.; Szwarc, M.; Naudan, M.; Bourgeon, G. Pre-treatment of soil samples rich in short-range-order minerals before particle-size analysis by the pipette method. Pedosphere 2013, 23, 20-28. [CrossRef]

28. Tamm, O. Eine Method zur Bestimmung der organischen Komponenten des Gelcomplexes in Boden. Medd. Statens Skogsfösöksanstalt 1922, 19, 385-404.

29. Singh, B.; Gilkes, R.J. Properties and Distribution of Iron Oxides and Their Association with Minor Elements in the Soils of South-Western Australia. J. Soil Sci. 1992, 43, 77-98. [CrossRef]

30. Trolard, F.; Bourrié, G.; Jeanroy, E.; Herbillon, A.J.; Martin, H. Trace metals in natural iron oxides from laterites: A study using selective kinetic extraction. Geochim. Comoschim. Acta 1995, 59, 1285-1297. [CrossRef]

31. Ciesielski, H.; Sterckeman, T.; Santerne, M.; Willery, J.-P. Determination of cation exchange capacity and exchangeable cations in soils by means of cobalt hexamine trichloride. Effects of experimental conditions. Agronomie 1997, 17, 1-7. [CrossRef]

32. Jeanroy, E.; Rajot, J.L.; Pillon, P.; Herbillon, A.J. Differential dissolution of hematite and goethite in dithionite and its application on soil yellowing. Geoderma 1991, 50, 79-94. [CrossRef]

33. Righi, D.; Girault, P.; Meunier, A. Transformation des phyllosilicates dans un sol cryptopodzolique humifère du plateau de Millevaches, France. Clay Miner. 1986, 21, 43-54. [CrossRef]

34. Klingelhöfer, G.; Morris, R.V.; Bernhardt, B.; Rodionov, D.; de Souza, P.A.; Squyres, S.W.; Foh, J.; Kankeleit, E.; Bonnes, U.; Gellert, R.; et al. Athena MIMOS II Mössbauer spectrometer investigation. J. Geophys. Res. 2003, 108, 8067-8082. [CrossRef]

35. Mitchell, B.D.; Smith, B.F.L.; Endredy, A.S. The effect of buffered sodium dithionite solution and ultrasonic agitation on soil clays. Israelian J. Chem. 1971, 9, 45-52. [CrossRef] 
36. Aurousseau, P.; Curmi, P.; Bouillé, S.; Charpentier, S. Les vermiculites hydroxy-alumineuses du massif Armoricain (France). Approches minéralogique, microanalytique et thermodynamique. Geoderma 1983, 31, 17-40. [CrossRef]

37. Farmer, V.C.; Smith, B.F.L.; Wilson, M.J.; Loveland, P.J.; Payton, R.W. Readily-Extractable Hydroxyaluminium Interlayers in Clay-and Silt-Sized Vermiculite. Clay Miner. 1988, 23, 271-277. [CrossRef] 